\title{
Gerakan Perlawanan Menolak Pembangunan Apartemen Studi Kasus : Dusun Balirejo, Kelurahan Muja Muju, Kec Umbulharjo, Kota Yogyakarta
}

\author{
Fraisel Dwi Permana, David Efendi, Alam Mahadika \\ Email : mahadikaalam@gmail.com \\ Prodi Ilmu Pemerintahan, Fakultas Ilmu Sosial dan Ilmu Politik, \\ Universitas Muhammadiyah Yogyakarta
}

\begin{abstract}
Abstrak
Tujuan penelitian ini menganalisis gerakan masyarakat melawan pembangunan apartemen yang terletak Dusun Balirejo Kelurahan Muja Muju Kecamatan Umbulharjo Kota Yogyakarta. Penelitian ini menggunakan metodologi penelitian Analisa kualitatif, jenis data dalam penelitian ini data primer dan sekunder, data yang didapatkan secara dokumentasi, observasi langsung lapangan serta wawancara kepada masyarakat Balirejo yang terdampak dan Dinas Sosial. Penelitian ini juga menggunakan data sekunder yang dikumpulkan dari studi terdahulu. Hasil yang temuan yaitu masyarakat menolak dikarenakan : a). Berdampak kepada sosial dengan timbulnya masyarakat eksklusif masuknya masyarakat modern yang akan berdampak kepada budaya. b). Kerusakan terhadap lingkungan seperti sumber daya kebutuhan air yang akan terganggu dan situasi saat proses pembangunan akan menganggu kehidupan masyarakat. Serta selanjutnya bentuk perlawanan dari masyarakat yaitu : a). Membuat petisi penolakan pembangunan yang akan diserah kepada aparat pemerintah. b) Memasang baliho dijalan bahkan didepan pembangunan apartemen. c) Melakukan audiensi kepada lembaga swadaya masyarakat dan aparat pemerintah. d). pengembalian surat keterangan pengurus RT dan RW disebabkan tidak menghadiri masyarakat ketika membahas AMDAL. Adapula dampak kehidupan masyarakat setelah perlawanan pembangunan apartemen adalah masyarakat lebih hati - hati terhadap informasi dan kejanggalan kondisi sosial masyarakat yang pro dan kontra terhadap pembangunan.
\end{abstract}

Kata Kunci : Pembangunan, Konflik Sosial, Gerakan Sosial

\begin{abstract}
This study aims to analyze the community's movement against the construction of an apartment located in Balirejo Hamlet, Muja Muju Village, Umbulharjo District, Yogyakarta City. This research uses qualitative analysis research methodology; the data types in this study are primary and secondary data, data obtained through documentation, direct field observations, and interviews with the affected Balirejo community and the Social Service. This study also uses secondary data collected from previous studies. The findings show that the city refuses due to: a). Social impact with the emergence of an entire society, the entry of modern society will affect culture. b). Damage to the environment, such as water resources that will be disrupted, and the situation during the development process will disrupt people's lives. And then the form of resistance from the community, namely: a). Making a petition against development that will be submitted to government officials. b) Put up billboards on the road, even in front of apartment construction. c) Conduct hearings with non-governmental organizations and government officials. d). the return of the certificate of RT and RW management was caused by not attending the community when discussing the AMDAL. There is also an impact on community life after resistance to apartment construction because people are more careful about information and irregularities in the community's social conditions: the pros and cons of development.
\end{abstract}

Keywords : Development, Social Conflict, Social Movements 


\section{Pendahuluan}

Tujuan penelitian ini untuk menganalisis bagaimana gerakan sosial dalam menolak perencanaan pembangunan apartemen yang ada di Dusun Balirejo, Kelurahan Muja Muju, Kecamatan Umbulharjo, Kota Yogyakarta.

Perencanaan pembangunan adalah rangkaian usaha pertumbuhan dan perubahan yang dilakukan dan direncanakan secara sadar oleh suatu Negara dan Pemerintah untuk menuju medernitas dalam rangka pembinaan bangsa. Pembangunan nasional ini mencakup seluruh aspek kehidupan bangsa, pembangunan didefenisikan sebagai kemajuan yang akan dicapai suatu masyarakat dalam bidang ekonomi, bahkan beberapa kondisi saat ini pembangunan diartikan sebagai bentuk kehidupan yang kurang baik bagi sebagian orang tersingkir maupula yang terdampak (Budiman, 1995).

Timbul - lah suatu permasalahan sosial (konflik sosial) dengan kehidupan masyarakat yang merasa tersingkirkan sebagaimana yang dijelaskan oleh Turner (1975) menunjukkan bahwa secara realitas konflik sosial dapat mengimplementasi ketidaknyamanan pada suatu individualis maupun kolektif yang terjadi disebabkan masalah ketidakkesetaraan (Turner, 1975).

Jonathan Turner dalam bukunya

The Ritual Process memiliki makna satu sisi dalam kelas sosial didalam siatuasi pembangunan dengan eksistensinya yakni senantiasa menimbulkan suatu kepentingan tertentu dibawah siatuasi yang diciptakan revolusi dalam wilayah orientasi melawan kelompok dominan dan pemilik modal dalam struktur kelas yang berjalan (Turner, 1996). Menurut Purnomo, mengatakan bahwa pembangunan adalah cara pandang yang tidak hanya terlhiat dari segi ekonomi saja tetapi harus juga menggabungkan tiga unsur yaitu keseimbangan sosial, keseimbangan lingkungan dan keseimbangan ekonomi. Pembangunan harus menciptakan kondisi dimana adanya konflik dalam proses pembangunan dapat diminimalisir atau bahkan tidak ada (Purnomo, 2007; Loucks, 2000).

Pembangunan berbandingan lurus dengan cepat pertumbuhan penduduk yang sangat cepat hingga mengakibatkan kebutuhan pumukiman juga semakin meningkat yang mana tidak diimbangi dengan lahan yang tersedia. Keterbatasan lahan di daerah perkotaan mengakibatkan tingginya harga tanah. Sebagai alternatif pemecahan masalah pengadaan pemukiman di daerah perkotaan dengan struktur vertikal bertingkat yang dikenal dengan istilah apartemen. Pembangunan rumah susun membutuhkan tanah jauh lebih sempit jika dibandingkan dengan pembangunan rumah secara konvensional, sehingga ketersediaan lahan terbuka lebih luas diwilayah kota yang dapat digunakan untuk menata kembali atau peremajaan daerah yang kumuh.

Di Yogyakarta pembangunan apartemen juga sudah banyak terjadi dibeberapa lokasi. Berdasarkan data Badan Pusat Statistik Kabupaten Sleman sampai 2016 ada 389 hotel di Kabupaten Sleman, terdiri dari 26 hotel berbintang dan 363 Hotel tidak bintang. Seiring berkembang tersebut akan terus mengalami pertambahan, secara tidak langsung dampaknya akan mengancam area persawahan di Kabupaten Sleman hal ini akan mengancam kelestarian lingkungan hidup diwilayah Kabupaten Sleman. Pembangunan fisik yang sedang 
marak belakangan ini juga diiri timbulnya gerakan sosial yang menolak pembangunan fisik. Berbagai gerakan penolakan menunjukan bahwa masyarakat kita sudah dewasa, bukan hanya sekadar menolak melainkan juga memiliki tujuan yang jelas. Perlawanan ini dikembangkan pada tujuan atau misi yang cerdas untuk upaya control terhadap kebijakan pemerintah (Yulianingsih, 2017).

Timbulnya gejolak pertentangan dari warang Dusun. Bermula dari rencana pembangunan apartemen yang akan dilakukan oleh pemilik modal melalui perizinan pemerintah. Wilayah dusun Balirejo yang berada di pusat perkotaan tentu tidak terlepas dari pembangunan, titik lokasi pembangunan tepat di dekat sungai Gajah Wong, Berdasarkan data yang didapatkan, menurut Dinas Lingkungan Hidup kota Yogyakarta sebagai pihak yang mengeluarkan izin lingkungan, lokasi pembangunan itu sudah tiga kali berganti pengembangan tercata pada tanggal 30 Maret 2015 pembangunan apartemen Majestic Grand Bale dengan atas nama PT. Kreasi Pratama Satu, setahun kemuadian masuk lagi surat permohonan izin kedua tercatat pada tanggal 2 November 2016 oleh PT. Mahardika Daya Inti untuk pembangunan atas nama apartemen Puri Notoprojo. Kemudian izin kembali masuk ketiga kalinya pada 2 Juni 2017 oleh PT. Abyudaya Tata Anugrah Mandiri dengan nama apartemen yang sama yaitu Puri Notoprojo (Putsanra, 2017).

Ketiga surat permohonan izin tersebut sudah dibalas oleh Dinas Lingkungan Hidup, tetapi sampai sekarang ketiga pihak pengembangan tersebut belum juga mengurus administrasi mengenai Analisis Mengenai Dampak Lingkungan (AMDAL), salah satu syarat yang harus melakukan pengurusan AMDAL adalah melawati proses persetujuan oleh warga yang diketahui ketua RT/RW, Dukuh, Camat dan Lurah. Sebelumnya dari pihak PT. Abyudaya Tata Anugrah Mandiri mengaku bahwa sebelumnya sudah pernah melakukan sosialisasi terkait pembangunan apartemen di Dusun Balirejo, namum pihak Dusun menolak untuk datang kerena pihak warga menolak keras terkait pembangunan apartemen tersebut (Kurniyatul, 2018).

Kemudian timbul aksi penolakan dari warga sebagai respon ketidaksetujuan terhadap pembangunan apartemen, mulai dari penyatuan kolektif warga masyarakat yang kemudian timbul petisi tulisan penolakan dalam satu benner dan aksi warga geruduk kantor satuan polisi pamong praja untuk mengklarifikasi rencana pembangunan apartemen di Kawasan tersebut melihat aksi yang dilakukan warga berhadil menguatkan isu penolakan baik dari pemerintah sehingga mampu meredam proses tahapan - tahapan pembangunan apartemen (Ismiyanto, 2017).

Berdasarkan dengan permasalahan yang teleah disebutkan diatas, maka peneliti tertatik untuk melakukan penelitian dengan membahas gerakan sosial dalam menolak pembangunan apartemen. Berdasarkan dengan latarbelakang masalah yang telah dipaparkan diatas maka dapat ditarik kesimpulan masalahnya yaitu bagaimana dinamika perlawanan masyarakat Balirejo dalam menolak pembangunan apartemen di Dusun Balirejo, Keluruahan Muja Muju, Kecamatan Umbullharjo, Kota Yogyakarta.

Penelitian ini menggunakan metodologi penelitian Analisa kualitatif metode yang sangat tepat untuk 
menjawab yang pokok pertanyaanya berkenaan dengan bagaiaman dan kenapa. Jenis data dalam penelitian ini yaitu data primer data yang diperoleh langsung dari objek yang akan diteliti melalui proses wawancara dan hasil pengamatan langsung dilapangan. Sumber data utama diperoleh dari Gerakan Masyarakat Balirejo dan data sekunder data yang didapatkan melalui sumber penelitian terdahalu untuk mengkohoransi data primer yang kurang. Teknik pengumpulan data melalui wawancara atau interview kepada Dinas sosial dengan dasar implementasi kebijakan yang telah dibuat dan bagaimana imbas dari implementasi itu. Dalam penelitian ini peneliti melakukan penelitian di Dusun Balirejo Kita Yogyakarta, dengan yang sudah dijelaskna dalam latarbelakang masalah gerakan sosial di Dusun Balirejo akibat adanya rencana pembangunan apartemen.

\section{Hasil Pembahasan}

\section{Masyarakat Balirejo Sebagai Gerakan Sosial}

Peneliti akan memulai pembahasan mengenai salah satu gerakan sosial yang menjadikan lingkungan sebagai alasan dilakukannya perlawanan masyarakat Balirejo. Penliti aka mengidentifikasi bahwa gerakan yang diawali dengan kesamaan prinsip untuk menjaga lingkungan untuk generasi penerus merupakan suatu gerakan sosial. Digunakan 4 indikator kepada masyarakat Balirejo sehingga dapat diambil kesimpulan bahwa masyarakat Balirejo sebagai gerakan sosial.

\section{A. Tantangan Kolektif}

Tarrow (Suharko, 2006) menjelaskan bahwa dalam gerakan sosial terdapat empat indikator - indikator yang digunakan yaitu tantangan kolektif. Keadaan untuk bersama bersama - sama menentang dengan melalui slogan. Sebagai gerakan yang terbentuk dari latar belakang oleh keinginan untuk menjaga kerusakan lingkungan. Kampung Balirejo menjadi terget untuk investor melebarkan sayap sejak tahun 2015 dengan niat mendirikan bangunan apartemen dan toko, namum karena tidak mendapatkan izin dari masyarakt. Pengembangan keuda ingin membangun dua toko besar dan pengembangan ketiga adalah sedang terjadinya pembangunan apartemen Puri Notoprojo. Seperti yang diceritakan sendiri mengani wawancara bersama masyarakat Balirejo selaku ketua RW 05 Balirejo :

Sebelumnya sudah ada penolakan dari kami, ini yang ketiga kalinya investor datang, yang pertama niatnya membangun apartemen, yang kedua toko besar tetapi kami menolak terus jadi dibangun terus yang ketiga apartemen lagi (Wawancara, 2019),

Mengenai ungkapan diatas bahwa tantangan kolektif terbentuknya perlawanan dari masyarakat secara bersama, untuk menghadapi pembangunan yang dapat membuat lingkungan menjadi tidak seimbang. Masyarakat tetap dengan kebersamaan untuk menolak. Penolakan yang dilakukan bukannya tanpa alasan tetapi warga ingin lingkungannya tidak rusak. Seperti yang diceritakan dalam wawancara dengamasyarakat Balirejo selaku ketua RT 49 Balirejo : 
Ini jalan kampung, jalannya daerah sini sudah macet, seumpama jika dibangun sekitar 300an kamar dan minimal ada kendaraan. Jadi akan pasti macet dan belum lagi dari limbahnya yang akan dibuang di kali (Wawancara, 2019).

Kegiatan penolakan yang dilakukan oleh sebagian masyarakat balirejo ternyata mendapatkan respon positif dari masyarakat sekitar meskipun ada beberpa masyarakt yang pro atas pembangunan apartemen seperti yang bilang oleh warga Balirejo ketua RW 05 :

Kalau ada yang masyarakat pro itu jelas ada, motifnya mereka diberikan iming - iming dibelakangnya, tetapi jumlah mereka tidak banyak, jadi yang pro dalam setiap rt itu pasti ada satu orang dengan niatan akan dijadikan ketua RT ataupun jadi petugas keamanan (Wawancara, 2019).

Kesadaran masyarakat yang sangat tinggi menjaga kelestarian lingkungan mereka menjadi hal yang sangat membantu dalam perjuagan menolak pembangunan apartemen Puri Notoprojo.

\section{B. Tujuan Bersama}

Teori Tarrow (Suharko, 2006) yang menjelaskan gerakan sosial terdapat indikator yang digunakan untuk mengukur yaitu adanya tujuan bersama untuk melakukan gerakan adalah melawan atau menentang pihak lain yang merugikan banyak pihak. Indidivu individu yang telibat dalam penolakan memang teridiri dari berbagai strata sosial, sehingga masyarakat memiliki kekuatan yang berlapis. Meskipun dari structur sosial banyak yang memiliki tingkatan yang berlapis dari struktur sosial banyak yang memiliki tingkat kualitas yang baik, tetapi banyak juga yang menolak jika akan dibangun apartemen diwilayah mereka. Seperti dikatakan oleh seorang warga Balirejo sebagai ketua RT 17 :

Kalau di daerah kami memang kebanyakan masyarakat yang perekonomian menengah dikebawah, tetapi yang dibelakang lokasi pembangunan itu yang tinggal orang - orang menengah keatas, jadi kami tidak mudah untuk dihasut (Wawancara, 2019). Bahaya akan kerusakan lingkungan menjadi pendorong pribadi masyarakat yang terlibat dalam gerakan menolak pembangunan apartemen. Masyarakat Belirejo melakukan pertemuan yang kemudian dituliskan dalam berita acara hasil pertemuan warga Balirejo menolak pembangunan apartemen. Masyarakat Balirejo melakukan pertemuan yang dihadiri warga Balirego meliputi : RT. 15, RT. 16, RT. 17, RT. 49, RT. 51 dan RT. 52 dan Kampung Tangguh Bencana Balirejo, adapun hasil pertemuan menetapkan sebagai berikut :

1. Warga Balirejo menolak rencana pembangunan apartemen disebabkan sama sekali tidak ada manfaatnya bagi warga.

2. Warga Balirejo melarang keras kepada ketua RT di Wilayah RW. 05 dan ketua RW, untuk menandatangi adminitrasi ataupun surat lainnya yang berkenaan dengan pengajuan izin rencana pembangunan. 
3. Warga Balirejo menyatakan tidak mengakui jika ada surat yang ditandatangi oleh oknum yang mengatasnamakan pengurus RT.50.

Tujuan dari penolakan masyarakat agar proses pembangunan dapat dibatalkan karena banyak masalah yang akan terjadi. Untuk saat ini gerakan perlawanan masyarakat Balirejo dapat dikatakan berhasil kerena proses pembangunan telah diberhentikan.

\section{Solidaritas Kolektif dan Identias Kolektif \\ Permasalahan yang menjadi faktor} masyarakat Balirejo bergerak adalah permasalahan yang terkait izin pembangunan dan masalah lingkungan. Salah satu warga Balirejo selaku ketua RW 05 menyatakan :

Kami mulai protes sebab pihak pengembangnya belum ada izin dari kami kemudian IMB nya belum keluar tetapi sudah melakukan pembangunan (Wawancara, 2019).

Penjelasan diatas sebelum melakukan pembangunan maka harus ada izin yang dikeluarkan oleh pemerintah dalam hal ini sesuai dengan yang disampaikan oleh Dinas Penanaman Modal dan Perizinan :

IMB itu sebagai langkah utama, kemudian dilihat kembali fungsi dan keguanaanya dan terkait gangguannya nanti harus ada rancangan terlebih dahulu (Wawancara, 2019).

Sesuai dengan peraturan Walikota nomor 85 Tahun 2018 yang mengatur perizinan terkait IMB. Pihak dinas belum mengeluarkan izin mendirikan bangunan karena AMDAL yang merupakan salah satu syarakt dikeluarkannya IMB belum dikeluarkan oleh Dinas Lingkungan Hidup. Atas dasar ketimpangan terjadilah membuat masyarakat untuk menolak pembangunan apartemen Balirejo, menurut wawancara diatas apabila rancangan pembangunan ini berlanjut maka dampak yang dirasakan masyarakat pasti sangat bersar terutama masalah lingkungan seperti pencemaran limbah, terganggunya air.

$$
\begin{aligned}
& \text { D. Memelihara Politik } \\
& \text { Perlawanan } \\
& \text { Dalam perjalan menghadapi }
\end{aligned}
$$
pembangunan Apartemen Puri Notoprojo masyarakat Balirejo mendapat tantangan. Seperti adu yang menjadi scenario untuk membuat antar warga berkonflik, namum dari pihak masyarakat sendiri tetap konsisten dan bersama - sama menentang pembangunan apartemen. Seusai dengan yang disampaikan oleh Ketua RW 05 Balirejo :

Saya sering mendapatkan tekanan, sering mereka datang untuk membahas. Kalau mereka datang secara rombongan, kami langsung chat digrup agar kami tetap solid, kami sudah menyerahkan kepada RT/RW masing - masing agar tetap menolak (Wawancara, 2019).

Dari ungkapan di atas dapat dilihat bahwa masyarkat mempercayai bahwa dengan kebersamaan yang dijaga akan membuat kekuatan yang besar untuk terus dapat berjuang menjaga daerah tempat tinggal mereka. 


\section{Perlawanan Masyarat Balirejo Terhadap Pembangunan Apartemen}

Pergerakan masyarakat Balirejo
dilakukan adalah kekhawatiran
lingkungan rusak dan tidak dapat
dirasakan untuk anak cucu, berikut
beberapa alasan penolakan masyarakat
Balirejo pembangunan yang berdampak
sosial seperti.

\section{A. Kesenjangan Sosial}

Ketakutan masyarakat Balirejo akan munculnya masalah sosial adalah dengan melihat bahwa sifat individual akan sangat tinggi. Hunian yang akan ditempati adalah memiliki desain seperti hotel berbtintang, maka masyarakat sangat khawatir akan munculnya batasan antara para penghuni apartemen dan masyarakat sekitar. Masyarakat merasa akan berkurangnya rasa simpati, toleransi, keakraban jika yang dihuni adalah masyarakat dari kalangan eksklusif, kekhawatiran ini juga disampaikan oleh warga Balirejo selaku ketua RT 17 :

Orang - orang yang tinggal diapartemen apakah nanti mereka mau ikut dengan kegiatan kesosialan warga disekitar, sepertinya tidak mungkin (Wawancara, 2019).

Seusai dengan yang ditegaskan warga Balirejo selaku ketua RW 05 :

Apa bedanya dengan hotel, kalau apartemen nanti dibangun, keterbatasan dengan warga nantinya pasti terjadi walaupun mengatasnamakan apartemen (Wawancara, 2019).

Menurut Peneliti warga Balirejo Sangat mencemaskan dampak sosial yang akan terjadi seperti yang terjadi diberbagai apartemen seperti tidak adanya interaksi sosial antara penghuni apartemen dan warga sekitar.

B. Keamanan Sekitar

Warga asli Balirejo tidak dapat mengawasi langsung aktivitas para penghuni Apartemen yang barangkali berpotensi terjadi penyalahgunaan narkoba, minuman keras, seks bebas. Seperti dikatakan oleh warga Balirejo tokoh masyarakat RT 52 :

Kami disini masih hidup dengan kearifan lokal, kami tidak ingin ada yang dilanggar. Apalagi jaman sekarang, miras sama obat obatan berbahaya (Wawancara, 2019).

Hal ini dikhawatirkan masyarakat Balirejo karena masyarakat tidak bisa sepenuhnya mengontrol keadaan yang ada diapartemen dan juga bertentangan dengan pola hidup masyarakat berbudaya.

C. Lingkungan

Menurut peneliti dampak lingkungan merupakan hal yang sensitive yang menjadi acuan masyarakat Balirejo melakukan gerakan menolak agar mereka tidak kelhilangan sumber daya untuk kebutuhan hidup, melihat kenyataan bahwa rencana pembangunan akan menggunakan air dari PDAM, namum warga tidak setuju dan khawatir kalau apartemen sampai berdiri. Perihal ini sesuai dikatakan oleh warga Balirejo RW 05 :

Beberapa tahun ini sumur didaerah Balirejo sudah menurun drastis tekanannya apalagi nanti dibagi dengan apartemen (Wawancara, 2019).

Menurut peneliti, apa yang diresahkan masyarakat Balirejo terkait sumber air yang berkurang sangat masuk akal. Sebab 
pernah terjadi kasus kekeringan yang melanda beberapa daerah Yogyakarta akibat pembangunan Apartemen maupun Hotel. Kasus kampung Balirejo yaitu Hotel Fave yang cukup viral terkait kasus kekeringan yang dirasakan oleh warga.

Adapula dampak berikutnya adalah polusi udara dengan proses pembangunannya akan sangat menganggu masyarakat sekitar seperti yang dikatakan oleh warga Balirejo RT 16 yang rumahnya tepat berada di depan lokasi pembangunan

Kemacetan sama polusi nanti akan menganggu warga apalagi dengan proses pembangunannya akan ada keluar masuknya mobil besar (Wawancara, 2019).

Isu penolakan mengenai polusi udara yang akan membahayakan masyarakat juga masuk akal untuk dijadikan alasn penolakan.

\section{Bentuk - Bentuk Perlawanan Masyarakat Balirejo}

Apartemen Puri Notoprojo yang nantinya akan dibangun disekitaran RW 05 sampai saat ini terus diawasi dan diupayakan oleh masyarakat agar tidak terjadi. Berikut beberapa bentuk perlawanan yang diupayakan oleh warga Balirejo khususnya RW 05 dan 06 dalam menolak pembangunan apartemen Puri Notoprojo.

A. Warga Belirejo RW 05 dan RW 06 Membuat Petisi Penolakan

Dalam memperjuangkan hak mereka atas daerahnya. Warga Balirejo melaui pengrus RT 05 dan RW 06 menyusun strategi dengan melakukan petisi yang ditandatangani oleh kedua pengurus RW 05 dan RW 06 menyusun strategi dengan melakukan petisi yang ditandatangani kedua pengurus. Isi dari petisi yang dituangkan dalam berita acara yang ditujukan kepada Walikota Yogyakarta, Komisi Pemberantasan Korupsi (KPK) Pusat Jakarta, Dinas Lingkungan Hidup Yogyakarta, Camat Umbulharjo dan Lurah Umbulharjo.

Tidak sampai disitu saja, bahkan warga membuat baliho dari hasil petisi yang dibuat telah ditandatangani dan distempel oleh perwakilan RT dan RW dipasang dipinggir jalan.

\section{B. Warga Balirejo Membuat Baliho}

Keinginan masyarakat untuk terus berjuang menolak pembangunan apartemen tidak berhenti hanya melalui petisi saja. Selain itu bentuk perlawanannya yaitu membuat dan memasang baliho disepanjang jalan kampung dan didepan lokasi pembangunan. Adapula biaya dari pembuatan baliho yaitu iuaran dan sukarelawan. Meskipun pemasangan baliho yang dilakukan warga tedapat perlawananm dengan sering adanya baliho tiba - tiba hilang dan robek oleh pihak yang tidak bertanggung jawab.

Membuat dan memasang baliho yang dilakukan oleh warga Balirejo cukup berguna. Baliho disini digunakan oleh masyarakat untuk mengkampanyekan dan mensosialisasikan kepada masyarakat luas terkait penolakan apartemen.

$$
\begin{aligned}
& \text { C. Warga Balirejo Melakukan } \\
& \text { Audiensi Kepada Satpol PP } \\
& \text { Yogyakarta, Kelurahan, DLH, } \\
& \text { Forpri dan Walhi }
\end{aligned}
$$

Warga yang menolak melakukan audiensi dengan pihak satpol PP terkait pembangunan apartemen sesuai dengan 
yang dikatakan warga Balirejo sekalu ketua RW 05 :

Semua intansi kami tembusi seperti DLH, camat, ombudsman, waktu itu kami juga megirim surat penolakan ke kelurahan terus forpi kami juga melakukan pertemuan dengan satpol PP (Wawancara, 2019).

Setelah melakukan audiensi dengan satpol PP, warga mendapatkan angin segar yang dilakukan oleh pihak Satpol PP akhirnya menutup proses pembangunan apartemen.

Langkah untuk melakukan audiensi yang dilakukan warga Balirejo sangat efektif dan bermanfaat. Terbukti bahwa beberapa hari setelah melakukan audiensi hingga akhirnya proyek apartemen disegel oleh Satpol PP.

D. Warga Kembalikan Surat Keputusan Pengangkatan Pengurus RT dan RW Kepada Kelurahan

Bentuk Perlawanan yang terakhir dilakukan oleh warga Balirejo adalah mengembalikan SK sebagai pengurus RT dan RW ke kelurahan dikarenakan pengurus resmi yang mewakili masyarakat tidak dilibatkan dalam sidang AMDAL. Menurut peneliti dari beberapa perlawanan yang dilakukan, pengebalian SK yang dilakukan oleh setiap RT dan RW sangat efektif. Terlihat bahwa pengembalian SK yang dilakukan akan berdampak kekosongan jabatan.

\section{Dampak Perlawanan Masyarakat Balirejo}

Bentuk penolakan yang dilakukan warga Balirejo terus berkembang. Setiap kejadian pasti akan memberikan dampak baik maupun buruk. Peneliti melihat kejadian yang ada dilapangan dan berdasarkan dari pengamatan diantaranya dampak perlawanan masyarakat yang terjadi di Balirejo yaitu.

A. Informasi Satu Arah

Masyarakat menjadi lebih hati - hati dan bungkam terhadap informasi. Warga memilih diam karena takut dengan kesalahan informasi yang diberikan. Sebab isu penolakan sangat sensitif.

\section{B. Perubahan Kondisi Sosial}

Terpecahnya masyarakat yang setuju dan tidak setuju. Meskipun yang setuju sedikit namum memiliki efek untuk keberlangsungan hidup. Hingga yang ditanamkan warga ialah tetap menerapkan hidup dengan budaya dan kearifan lokal sebagai landasan untuk bersatu.

\section{Kesimpulan}

Penolakan terhadap apartemen bukannya tanpa alasan. Warga Balirejo memiliki alasan yaitu akan berdampak kepada akses sosial, berdampak kepada akses fisik, berdampak pada akses lingkungan. Alasan kuat itulah yang membuat masyarakat terus berjuang untuk menolak pembangunan apartemen. Beberapa bentuk perlawanan seperti membuat petisi penolakan, membuat dan memasang baliho, membuat audiensi kepada aparat pemerintah dan terkahir memberikan surat keputusan pengurus RT dan RW kepada kelurahan sebagai tanda kekecewaan dari para ketua dan wakil masyarkat yang tidak dilibatkan dalam sidang AMDAL.

\section{Daftar Pustaka}

\section{Buku}

Suharko. 2004. Gerakan Sosial, Konsep, Stretegi, Aktor, Hamdatan Dan Tantangan Gerakan Sosial Di Indonesia. Malang: Fakultas Ekonomi Universitas Indonesia. 
Turner, Victor. 1996. The Process : Structure and Anti - Structure. Somerset: AldineTransaction.

\section{Jurnal}

Mahadika, Alam. 2020. "Analisis Konflik Sosial Pembangunan Pelabuhan Internasional Terhadap Kehidupan Masyarakat Desa Sungai Kunyit Provinsi Kalimantan Barat." Jurnal Mukadimah Vol 4(No 2):101-7.

Purnomo, Eko Priyo. 2018. "Analisis Kebijakan Alih Fungsi Lahan Pertanian Ke Non Pertanian Di Kabupaten Klaten Tahun 2013 - 2016 (Stdui Kasus Kecamatan Ceper Kabupaten Klaten)." Jispo Vol. 8 No.

Purnomo, Eko priyo. 2019. "Land Ownership Transformation Before And After Forest Fires In Indonesian Palm Oil Plantation Areas." Journal Of Land Use Science 1-15.

\section{Media}

Ismiyanto. 2017. “Tolak Apartemen, Warga Balirejo Geruduk Sat Pol PP Kota Yogyakarta." Jogjatribun. Retrieved July 20, 2018

(htpps://www.jogja.tribunnews.com/ 2018/09/17/warga-pertanyakanamdal-dan-imb-apartemen-dhikauniverse-yang-dikeluarkan-pemkotyogya).

Kurniyatul. 2018. "Warga Pertanyakan Amdal Dan IMB Apartemen Dhika Universe Yang Dikeluarkan Yogya." Jogjatribun. Retrieved (htpps://www.jogja.tribunnews.com/ 2018/09/17/warga-pertanyakanamdal-dan-imb-apartemen-dhikauniverse-yang-dikeluarkan-pemkotyogya).

Videlia, Dipna Putsanra. 2017. "Warga Yogya Menolak Pembangunan Hotel Dan Apartemen." Tirto.Id. Retrieved July 10, 2017 (https://tirto.id/warga- yogya-menolak-pembangunan-hoteldan-apartemen-csjG).

Yulianingsih. 2017. "Warga Desak Pemkot Yogya Tindak Tegas Pembangunan." Republika. Retrieved (https://republika.co.id/berita/opdm 47291/warga-desak-pemkot-yogyatindak-tegas-pembangunanapartemen-ilegal). 